\title{
Ruminal and Intestinal Degradability of Distillers Grains plus Solubles Varies by Source ${ }^{1}$
}

\author{
D. H. Kleinschmit, J. L. Anderson, D. J. Schingoethe ${ }^{2}$ K. F. Kalscheur, and A. R. Hippen \\ Dairy Science Department, South Dakota State University, Brookings 57007
}

\begin{abstract}
Currently in the dairy industry, there is a concern about the variability in the nutrient content among sources of distillers grains plus solubles (DG), but little research has evaluated the variability in metabolizable AA among sources. The ruminal degradability of crude protein $(\mathrm{CP})$ in soybean meal (SBM), dried DG from 5 sources (DG1, DG2, DG3, DG4, and DG5), and 1 source of wet DG (WDG) were determined using 2 lactating ruminally cannulated Holstein cows. Feeds were incubated in the rumen for $3,6,12,18,24$, and $36 \mathrm{~h}$. Intestinal CP digestibility via pepsin and pancreatin and AA profiles were measured on residue from 12-h ruminal incubation of feeds. Ruminal undegradable protein (RUP) was less for SBM (46.4\%) than for DG. The WDG (53.6\%) had less RUP than dried DG. The RUP concentrations of DG3 (59.1\%) and DG5 $(60.3 \%)$ were lower than DG1 $(71.7 \%)$ and DG4 (67.5\%), with DG1 having more than DG2 (63.7\%) and DG4. Intestinal digestibility of RUP was greater for SBM (86.7\%) than DG. The DG2 (76.8\%) and DG3 $(74.2 \%)$ had greater intestinal digestibility compared with DG1 (59.2\%), DG4 (63.0\%), and DG5 (68.1\%). The intestinal digestibility in WDG $(65.8 \%)$ was similar to all other DG except for DG1, which was lower. Total digestibility of CP was greater in SBM $(93.9 \%)$ compared with DG. Among the DG sources, the CP in DG2 (85.3\%) and DG3 (84.9\%) was more digestible compared with DG1 (70.7\%), DG4 (74.9\%), and DG5 (80.8\%) but not WDG (81.9\%). Based on the milk protein score (MPS), which is an estimate of the proportion of milk protein that a protein source can sustain until the first limiting AA is depleted, Met was the first limiting AA in SBM and Lys in DG. The concentrations of essential AA in the RUP were not different among DG sources, but the greater MPS in WDG

\footnotetext{
Received September 19, 2006.

Accepted January 23, 2007.

${ }^{1}$ Published with the approval of the director of the South Dakota

${ }^{2}$ Corresponding author: david.schingoethe@sdstate.edu
} Agricultural Experiment Station as publication number 3532 of the journal series.
\end{abstract}

(0.306) compared with the dried DG (0.240) sources indicated that WDG may have been the more ideal RUP source; but, the MPS of the metabolizable protein indicated that the protein quality of WDG was similar to that in DG2, DG3, and DG5. In conclusion, protein degradability and digestibility differed greatly among DG sources, but these differences were actually not as prominent in the concentrations of metabolizable AA and MPS among these sources.

Key words: distillers grains, protein, digestibility

\section{INTRODUCTION}

The rapid growth of the ethanol industry in the United States has made large quantities of distillers grains plus solubles (DG) available for feeding to dairy cattle. Factors such as grain variability, extent of starch extraction, amount of solubles added back, and, in the case of dried DG (DDG), the extent of drying and temperature may significantly affect the nutrient content and digestibility of DG. In a 3-yr study, Spiehs et al. (2002) recorded the variation in nutrient content of DDG among 10 ethanol plants in South Dakota and Minnesota ( $\mathrm{n}=118)$. In that study, the CP content ranged from 28.7 to $31.6 \%(\mathrm{CV}=6.4 \%)$, fat content from 10.2 to $11.7 \%$ (CV $=7.8 \%$ ), and NDF content from 36.7 to $49.1 \%(\mathrm{CV}=14.3 \%)$.

The protein in DG is moderately resistant to ruminal degradation, thus making it an excellent source of RUP. Based on past research, the RUP of DG has been assumed to be from 47 to $54 \%$ of the CP (Firkins et al., 1984). However, in an in situ study, Brouk (1994) found the RUP of various sources of distillers grains to be variable, ranging from 53.5 to $87.2 \%$ of the CP. In both studies, the RUP of wet DG (WDG) was estimated to be on the lower end of this range, because it does not undergo the extra drying process that DDG does. This may damage a considerable portion of the protein, making it unavailable to the animal.

Lysine is usually the first-limiting AA for milk protein synthesis when feeding diets containing high levels (approximately 20\% of diet) of DG to dairy cattle (Nichols et al., 1998; Liu et al., 2000; Kleinschmit et al., 2006). An accurate prediction of the quantity of 
metabolizable AA from DG will allow one to balance dairy cattle diets with high DG inclusion rates without the concern of a Lys deficiency that may decrease milk protein synthesis. The objectives of this study were to evaluate ruminal CP degradability, intestinal digestibility of RUP, and the postruminal AA profile of various sources of DG to determine if the differences in their contribution to metabolizable AA may potentially affect milk protein synthesis in lactating dairy cows.

\section{MATERIALS AND METHODS}

Ruminal CP degradability, RUP intestinal digestibility, and postruminal AA profile in soybean meal (SBM); 5 sources of DDG (DG1, DG2, DG3, DG4, and DG5), and 1 source of WDG were determined using 2 ruminally cannulated Holstein cows (261 and 265 DIM) producing 34 and $29 \mathrm{~kg} / \mathrm{d}$ of milk. The cows also consumed 25.9 and $22.7 \mathrm{~kg}$ of DM/d and weighed 680 and $623 \mathrm{~kg}$. All sources of DG were processed under proprietary methods, but details were not disclosed to the authors. In particular, DG2 and DG3 were processed to provide a DDG with superior quality. The DG5 and WDG sources originated from the same ethanol plant and were processed using similar methods, with the exception of DG5 being dried. Cows were fed a TMR for ad libitum consumption (Table 1) and housed in individual pens equipped with feeders and clean water where they were fed once and milked 3 times daily. The study was conducted over a period of $6 \mathrm{~d}$ with a 12 -h interval between measurement days for a total of three 36 -h sampling periods.

Before the experiment, feeds were analyzed for NDF (Van Soest et al., 1991) and sequentially analyzed for neutral detergent insoluble protein. Sodium sulfite was omitted from the NDF procedure to determine neutral detergent insoluble protein, as described by Licitra et al. (1996). The ADF (Robertson and Van Soest, 1981) was determined sequentially by using an Ankom fiber analyzer with the filter bag technique (Ankom Technology Corp., Fairport, NY), CP, and ash (AOAC, 2000). Crude protein was determined via macro-Kjeldahl (AOAC, 2000) and fractionated into A, $\mathrm{B} 1, \mathrm{~B} 2, \mathrm{~B} 3$, and $\mathrm{C}$ fractions to characterize the chemical properties of the protein in the feeds as described by Licitra et al. (1996). This method for CP fractioning is used by the Cornell Net Carbohydrate and Protein System (CNCPS; Sniffen et al., 1992) to predict ruminal degradability and intestinal digestibility. The ash content was determined as well (AOAC, 2000). Color score was determined on DDG samples using a LabScan XE spectrocolorimeter (Hunter Associates Laboratory, Reston, VA) with the lightness, redness, and yellowness opposable color scales (Hunter Associates
Table 1. Composition of the diet fed to cows during the in situ experiment

\begin{tabular}{|c|c|}
\hline Ingredient & $\mathrm{DM}, \%$ \\
\hline Corn silage & 21.74 \\
\hline Alfalfa hay, chopped & 12.18 \\
\hline Alfalfa haylage & 6.63 \\
\hline Wet distillers grains & 8.28 \\
\hline High-moisture corn & 18.69 \\
\hline Ground corn, shelled & 6.07 \\
\hline Soybean meal, $44 \% \mathrm{CP}$ & 3.23 \\
\hline SoyPlus ${ }^{1}$ & 4.56 \\
\hline Fish meal & 0.40 \\
\hline Whole cottonseed & 8.90 \\
\hline Megalac-R ${ }^{2}$ & 1.28 \\
\hline Energizer $4-19 \mathrm{~W}^{3}$ & 4.23 \\
\hline Calcium carbonate & 0.97 \\
\hline Pork meat and bone meal & 0.64 \\
\hline Sodium bicarbonate & 0.57 \\
\hline Salt & 0.50 \\
\hline Vitamin A, D, and E premix ${ }^{4}$ & 0.31 \\
\hline Yeast culture ${ }^{5}$ & 0.21 \\
\hline Magnesium oxide & 0.17 \\
\hline MTB- $100^{6}$ & 0.15 \\
\hline Urea & 0.17 \\
\hline Sel-Plex $600^{7}$ & 0.05 \\
\hline $4-\mathrm{Plex}^{8}$ & 0.05 \\
\hline Vitamin E premix $(44,000 \mathrm{IU} / \mathrm{kg})$ & 0.02 \\
\hline
\end{tabular}

${ }^{1}$ West Central Soy, Ralston, IA. SoyPlus is a heat-processed soybean meal (assay DM basis: 50\% CP, 60\% RUP).

${ }^{2}$ Church \& Dwight Co. Inc, Princeton, NJ. Contained Ca salts of long-chain fatty acids (assay DM basis: $82.5 \%$ fatty acids, 8.5 to $10.2 \%$ $\mathrm{Ca}$.

${ }^{3}$ Quality Liquid Feeds Inc., Dodgeville, WI. Liquid mixture of cane molasses, condensed whey, and tallow (assay DM basis: $5.7 \%$ protein, $27 \%$ fat)

${ }^{4}$ Dairy Micro Premix, Land O' Lakes, Fort Dodge, IA (assay DM basis: $10 \% \mathrm{Mg}, 9,840 \mathrm{ppm}$ of $\mathrm{Fe}, 120 \mathrm{ppm}$ of $\mathrm{Cu}, 26,000 \mathrm{ppm}$ of $\mathrm{Mn}$, $26,000 \mathrm{ppm}$ of $\mathrm{Zn}, 400 \mathrm{ppm}$ of I, $140 \mathrm{ppm}$ of Se, 909,000 IU/kg of vitamin A, 182,000 IU/kg of vitamin D, 2,424 IU/kg of vitamin E).

${ }^{5}$ Diamond V XP, Diamond V Mills Inc., Cedar Rapids, IA. Contained Saccharomyces cerevisiae yeast and the media on which it was grown.

${ }^{6}$ Alltech Biotechnology, Nicholasville, KY. Contained mycotoxin binder.

${ }^{7}$ Alltech Biotechnology. Contained 600 ppm of Se from S. cerevisiae yeast.

${ }^{8}$ Zinpro Corp., Eden Prairie, MN. Zinc and Mn Met complex, $\mathrm{Cu}$ Lys complex, and Co glucoheptonate.

Laboratory, 2002). Particle size distribution and geometric mean diameter were determined on the DDG samples using a Rototap shaker sieve (model RX-29, W. S. Tyler, Mentor, OH; ASAE, 2004).

Samples (5 g; DM basis) of the respective feed sources were placed in $10 \times 20 \mathrm{~cm}$ Dacron bags (53 \pm $10 \mu \mathrm{m}$ pore size; Ankom Products) with heat-sealed seams. These feed samples were not ground through a $2-\mathrm{mm}$ screen as is commonly done on samples used for in situ evaluation (NRC, 2001). Duplicate samples of each feed were soaked in $39^{\circ} \mathrm{C}$ water for $20 \mathrm{~min}$, placed into a larger nylon mesh bag $(36 \times 42 \mathrm{~cm})$ with a nylon zipper, and incubated in the rumen for their respective times. In situ measures were taken at 3,6 , 
$12,18,24$, and $36 \mathrm{~h}$ with Dacron bags placed in the rumen in decreasing order of incubation time and all removed at the same time. Four extra samples of each feed were incubated in the rumen for $12 \mathrm{~h}$ and composited by cow within each day to supply 6 samples per feed for AA analysis via HPLC (model 1100, Agilent Technologies Inc., Palo Alto, CA) with a PCX 5200 postcolumn derivatizer (Pickering Laboratories Inc., Mountain View, CA) as described by the AOAC (2000). Performic acid oxidation was performed on feed samples before hydrolysis with $6 \mathrm{M} \mathrm{HCl}$ to prevent destruction of the Cys and Met (AOAC, 2000). The intestinal digestibility of RUP (IDP) via incubation with pepsin and pancreatin was conducted, as described by Calsamiglia and Stern (1995) after being ground to pass through a 1-mm screen of a Wiley mill (model 3; Arthur H. Thomas Co., Philadelphia, PA).

Mesh bags were placed into 20 -L buckets following ruminal incubation, gently agitated, and rinsed with cold tap water. The individual Dacron bags were further rinsed with cold tap water until the water ran clear, allowed to drain overnight, and then oven-dried at $55^{\circ} \mathrm{C}$ for $48 \mathrm{~h}$. The 0 -h samples underwent the same soaking and washing procedure as described to estimate the amount of water-soluble CP. Two blank bags for each time exposure were incubated with the samples to correct for microbial attachment (Poos-Floyd et al., 1985). Residues of the feeds after ruminal incubation were analyzed for CP as described. Samples were corrected to $100 \%$ DM basis by drying an aliquot of the composites at $105^{\circ} \mathrm{C}$ for $24 \mathrm{~h}$. Crude protein disappearance were calculated by difference of original amounts and amounts remaining after ruminal incubation. Ruminally available CP were estimated using the NLIN procedure of SAS Institute (1999) as described by Ørskov and McDonald (1979) and McDonald (1981) and the fractional passage rate was calculated to be $0.068 / \mathrm{h}$ (NRC, 2001).

Analysis of variance was conducted using the MIXED procedure of SAS (Littell et al., 1996; SAS Institute, 1999). The model for CP disappearance at each time point was $\mathrm{Y}=$ treatment + time + day + treatment $\times$ time, using cow as a random variable. The model for CP degradation rates, RUP, and AA was $\mathrm{Y}=$ treatment + day, using cow as a random variable. Significance was declared at $P<0.05$. Least squares differences were used for means separation.

\section{RESULTS AND DISCUSSION}

\section{Chemical and Physical Composition of Feeds}

The chemical composition of the feeds used in this study is shown in Table 2. The CP of WDG (32.6\%) was similar to the DDG used in this study, which varied slightly among sources ranging from 30.6 to $33.5 \%$ $(\mathrm{CV}=3.60)$. The soluble CP fraction (sum of A and B1 fractions) in the DDG used in this study contributed 5.27 to $10.7 \%$ of the $\mathrm{CP}$, which was similar to that found in WDG (8.34\% of CP) and greater than that found in SBM (2.86\% of CP). Harty et al. (1998) found that the soluble protein from DDG ranged from 6.0 to $12.6 \%$ of the $\mathrm{CP}$ when samples were taken from eight different plants. The protein fractions in SBM consisted of 86.7, 7.63, and $2.76 \%$ in the B2, B3, and C fractions, respectively. Globulin proteins constitute the majority of the protein in SBM (Clark et al., 1987). Due to their low molecular weight, they are highly degradable in the rumen, which explains the high proportion of the B2 protein fraction compared with the less available fractions in this protein source. Corn protein consists primarily of prolamin and glutelin proteins. These proteins are highly resistant to ruminal degradation because they have a higher molecular weight and are held together by disulfide bridges (Clark et al., 1987). This explains why much less of the $\mathrm{CP}$ was found in the $\mathrm{B} 2$ fraction in DDG (average of $45 \%$ of $\mathrm{CP}$; CV $=9.75)$ and WDG $(60.9 \%$ of the CP) compared with SBM. The B3 (22.7 to $41.4 \%$ of CP; $\mathrm{CV}=21.8)$ and $\mathrm{C}(7.45$ to $23.1 \%$ of $\mathrm{CP} ; \mathrm{CV}=49.9)$ protein fractions in the DDG were variable among sources. Harty et al. (1998) found that the C fraction had a range of 4.9 to $11.6 \%$ of the $\mathrm{CP}(\mathrm{CV}=33.8)$. The DG1 source had a much greater proportion of the CP in the $\mathrm{C}$ fraction and less in the soluble CP fraction compared with the other sources, which suggests that it probably underwent more extensive heating. Drying DDG decreased the proportion of CP in the B2 fraction and increased the proportions of $\mathrm{B} 3$ and $\mathrm{C}$ protein fractions compared with WDG. Excessive heating, as what appeared to have occurred in DG1, decreased the B3 fraction because more protein was damaged and incorporated into the $\mathrm{C}$ fraction.

The NDF content varied among DG sources but much of the NDF was bound $\mathrm{CP}(27.1,30.8,35.0,35.8$, 24.6, and $20.7 \%$ of NDF for DG1, DG2, DG3, DG4, DG5, and WDG, respectively). The ADF content was much greater in DG1 compared with all other DG because of ADICP, or C fraction, in the sample that was possibly caused by excessive heating. The $\mathrm{C}$ fraction has generally been assumed to be unavailable because it has been well established that there is a strong negative relationship between ADICP and CP digestibility in forages (Goering et al., 1972; Yu and Thomas, 1976). However, past animal studies have found ADICP to be a poor indicator of protein digestibility (Weiss et al., 1989; Nakamura et al., 1994). Nakamura et al. (1994) found the digestibility of various sources of DDG to be similar in CP digestibility but the ADICP 
Table 2. Chemical composition of the soybean meal (SBM), 5 sources of dried distillers grains plus solubles (DG1, DG2, DG3, DG4, and DG5), and wet distillers grains plus solubles (WDG) used in this study

\begin{tabular}{|c|c|c|c|c|c|c|c|c|}
\hline \multirow[b]{2}{*}{ Item } & \multicolumn{7}{|c|}{ Feed } & \multirow[b]{2}{*}{$\mathrm{CV}^{1}$} \\
\hline & SBM & DG1 & DG2 & DG3 & DG4 & DG5 & WDG & \\
\hline DM, \% & 88.9 & 89.6 & 87.5 & 88.0 & 88.2 & 90.7 & 31.6 & \\
\hline $\mathrm{CP}^{2}$ & 51.0 & 31.3 & 32.1 & 32.8 & 33.5 & 30.6 & 32.6 & 3.60 \\
\hline $\mathrm{A}, \%$ of $\mathrm{CP}$ & 0.65 & 5.21 & 7.89 & 5.63 & 7.01 & 9.84 & 8.34 & 26.2 \\
\hline $\mathrm{B} 1, \%$ of $\mathrm{CP}$ & 2.22 & 0.07 & 1.64 & 1.78 & 1.37 & 0.85 & 0.00 & 61.0 \\
\hline $\mathrm{B} 2, \%$ of $\mathrm{CP}$ & 86.75 & 48.91 & 43.40 & 40.90 & 42.39 & 51.11 & 60.86 & 9.75 \\
\hline $\mathrm{B} 3, \%$ of $\mathrm{CP}$ & 7.63 & 22.68 & 37.71 & 41.41 & 37.34 & 30.75 & 26.07 & 21.8 \\
\hline $\mathrm{C}, \%$ of $\mathrm{CP}$ & 2.76 & 23.14 & 9.36 & 10.27 & 11.88 & 7.45 & 4.72 & 49.9 \\
\hline NDICP $^{3}$ & 5.30 & 13.90 & 14.08 & 16.25 & 16.49 & 11.69 & 10.04 & 13.6 \\
\hline $\mathrm{NDF}^{4}$ & 9.40 & 37.4 & 31.6 & 30.2 & 29.5 & 35.9 & 38.6 & 10.7 \\
\hline $\mathrm{ADF}$ & 6.33 & 20.3 & 15.1 & 15.2 & 14.7 & 14.7 & 15.7 & 15.1 \\
\hline Ash & 7.19 & 4.58 & 5.16 & 5.48 & 5.38 & 4.46 & 3.77 & 14.5 \\
\hline
\end{tabular}

${ }^{1} \mathrm{CV}$ among DG1, DG2, DG3, DG4, and DG5.

${ }^{2} \mathrm{~A}=$ nonprotein $\mathrm{N}$; $\mathrm{B} 1$ = soluble true protein; $\mathrm{B} 2$ = intermediately degradable true protein; $\mathrm{B} 3$ = slowly degradable true protein; $\mathrm{C}=$ unavailable protein (acid detergent insoluble $\mathrm{CP}$ ).

${ }^{3} \mathrm{NDICP}=$ neutral detergent insoluble $\mathrm{CP}$.

${ }^{4} \mathrm{NDF}$ corrected for neutral detergent insoluble CP.

was highly variable among the DDG (7.8 to to $27.9 \%$ of $\mathrm{CP}$ ).

Recently, there has been a growing interest in the color score of DG and how this relates to CP quality, especially ADICP concentration. Cromwell et al. (1993) found that decreasing color score and greater ADICP concentrations in DDG were highly correlated linearly $(r=0.79)$. In contrast, Harty et al. (1998) found this relationship to be poorly correlated, except when DDG containing less than $13 \%$ of CP as ADICP were excluded from the correlation $(r=0.80)$. The ADICP content of the DDG used by Cromwell et al. (1993) were greater (average of $22.4 \%$ of $\mathrm{CP}$ ) than that used in the by Harty et al. (1998; average of $8.0 \%$ of CP). Based on those experiments, using color as an indicator of DDG quality, in relation to ADICP, may be appropriate only when the feed contains a high concentration of ADICP. However, those experiments only reported linear relationships and it may have been more appropriate to also regress with a nonlinear model to investigate if color score may actually have a curvilinear relationship. Removal of the samples containing less than 13\% ADICP may have actually masked this relationship. The color of the DDG (Table 3 ) in this experiment, agree with that observed by Harty et al. (1998), such that color score appears to have little linear relation to the concentration of $\mathrm{AD}$ ICP in the feeds.

The particle size distribution of the DDG used in this experiment is shown in Table 4. The ranking of the geometric mean diameter of these samples from largest to smallest was DG2 $(1.18 \mathrm{~mm}), \mathrm{DG} 4(1.01$ $\mathrm{mm})$, DG1 (0.74 mm), DG3 (0.51 mm), and DG5 (0.46 $\mathrm{mm})$. The standard in situ procedure recommends using feed samples that have been dried and ground through a 2-mm screen (NRC, 2001), which was not done in this study. Grinding these feeds negate some of the physical properties that may affect feed degradability in the animal, such as moisture content and microbial access to the protein sources (Stern et al., 1994), particularly in relation to particle size. This may be an issue in DDG because particle size may vary widely as shown in Table 4 .

The physically effective NDF, as determined by Santini et al. (1983), ranged from 3.44 to 19.8. Even though there is a wide range, these values indicated that the DDG used in this experiment, regardless of source, provide little effective fiber and may not be suitable replacements for forage. Cyriac et al. (2005) found that replacing corn silage with increasing concentrations of DDG $(7,14$, and $21 \%$ of dietary DM) decreased milk fat percentage linearly. The authors postulated that

Table 3. Color score of dried distillers grains (DDG) plus solubles (DG1, DG2, DG3, DG4, and DG5) used in this experiment

\begin{tabular}{lccc}
\hline & \multicolumn{3}{c}{ Hunter Lab color score $^{1}$} \\
\cline { 2 - 4 } Item & $\mathrm{L}^{*}$ & $\mathrm{a}^{*}$ & $\mathrm{~b}^{*}$ \\
\hline DG1 & 33.8 & 8.48 & 14.9 \\
DG2 & 32.0 & 10.0 & 14.9 \\
DG3 & 41.7 & 11.0 & 19.5 \\
DG4 & 39.6 & 6.94 & 13.9 \\
DG5 & 41.5 & 10.2 & 18.8 \\
CV & 12.0 & 17.3 & 15.6 \\
\hline
\end{tabular}

${ }^{1} \mathrm{~L}^{*}=$ lightness of sample; $0=$ black; $100=$ white. The greater the value of $a^{*}$ and $b^{*}$, the greater degree of redness and yellowness, respectively. 
Table 4. Particle size distribution and mean particle size of dried distillers grains (DDG) plus solubles (DG1, DG2, DG3, DG4, and DG5) used in this experiment

\begin{tabular}{lrrrrrr}
\hline & \multicolumn{7}{c}{ DDG } & \\
\cline { 2 - 5 } Item & DG1 & DG2 & DG3 & DG4 & DG5 & CV \\
\hline US sieve size, mm & & & & & & \\
2.28 & 6.01 & 11.43 & 2.69 & 4.59 & 0.17 & 84.8 \\
1.68 & 8.14 & 19.40 & 4.64 & 14.19 & 0.91 & 78.3 \\
1.19 & 17.18 & 31.70 & 10.32 & 32.75 & 8.49 & 57.5 \\
0.841 & 20.24 & 25.05 & 13.89 & 29.45 & 17.32 & 29.1 \\
0.595 & 20.11 & 15.64 & 5.88 & 18.53 & 23.14 & 39.7 \\
0.42 & 8.22 & 6.97 & 11.75 & 8.02 & 17.42 & 40.9 \\
0.297 & 7.47 & 0.77 & 12.07 & 1.39 & 10.04 & 80.1 \\
0.210 & 4.17 & 1.07 & 12.30 & 1.39 & 6.66 & 90.1 \\
0.149 & 2.03 & 0.63 & 10.84 & 0.78 & 5.31 & 110.1 \\
0.105 & 4.42 & 0.30 & 4.13 & 0.75 & 11.27 & 105.0 \\
0.074 & 1.92 & 0.02 & 0.16 & 0.83 & 3.07 & 107.3 \\
0.053 & 0.10 & 0.00 & 0.00 & 0.00 & 0.00 & 223.6 \\
Geometric mean $^{2}$ & 0.74 & 1.18 & 0.51 & 1.01 & 0.46 & 40.2 \\
PENDF $^{2}$ & 11.7 & 19.8 & 5.32 & 15.2 & 3.44 & 61.3 \\
\hline
\end{tabular}

${ }^{1}$ Determined as described by ASAE (2004).

${ }^{2}$ PENDF = physically effective NDF (Santini et al., 1983).

this was likely an effect of the combination of low effective fiber in the diet and the high concentrations of unsaturated fat in DDG.

\section{CP Degradability}

The lag time for protein degradation differed little among the protein sources and ranged from 0.37 to $1.75 \mathrm{~h}$ (Table 5). The NRC (2001) assumed the fraction that is immediately soluble in DDG to be $28.5 \%$ of the
$\mathrm{CP}$ but the range of this fraction for all DG varied from 13.4 to $19.7 \%$ of the CP. In SBM, the NRC (2001) assumed this fraction to be $15 \%$ of the CP which is relatively similar to that observed in this experiment (12.4\% of CP). The ruminally degradable CP fraction was $87.6 \%$ for SBM and a range of 63.0 to $80.7 \%$ for $\mathrm{DG}$, which was relatively similar to that assumed in the NRC (2001; 84.1 and 63.3 for SBM and DDG, respectively). The rate of CP degradation was greater in $\operatorname{SBM}(0.062 / \mathrm{h})$ compared with the DG sources with the

Table 5. Crude protein degradation parameters of soybean meal (SBM), 5 sources of distillers dried grains plus solubles (DG1, DG2, DG3, DG4, and DG5), and wet distillers grains plus solubles (WDG) after ruminal incubation $^{1}$

\begin{tabular}{lcccccccc}
\hline & \multicolumn{7}{c}{ Feed } & \\
\cline { 2 - 7 } Item & SBM & DG1 & DG2 & DG3 & DG4 & DG5 & WDG & SE \\
\hline CP & & & & & & & & \\
Lag, h & $0.88^{\mathrm{ab}}$ & $1.53^{\mathrm{a}}$ & $0.98^{\mathrm{ab}}$ & $0.42^{\mathrm{b}}$ & $1.75^{\mathrm{a}}$ & $1.63^{\mathrm{a}}$ & $0.37^{\mathrm{b}}$ & 0.37 \\
$\mathrm{~A},{ }^{2} \%$ of CP & $12.4^{\mathrm{d}}$ & $13.4^{\mathrm{d}}$ & $18.3^{\mathrm{abc}}$ & $19.7^{\mathrm{a}}$ & $15.9^{\mathrm{c}}$ & $16.9^{\mathrm{bc}}$ & $19.0^{\mathrm{ab}}$ & 0.90 \\
B, \% of CP & $87.6^{\mathrm{a}}$ & $75.2^{\mathrm{abc}}$ & $63.0^{\mathrm{c}}$ & $67.8^{\mathrm{bc}}$ & $78.7^{\mathrm{ab}}$ & $80.7^{\mathrm{ab}}$ & $78.9^{\mathrm{ab}}$ & 5.19 \\
Rate, per h & $0.062^{\mathrm{a}}$ & $0.019^{\mathrm{c}}$ & $0.037^{\mathrm{bc}}$ & $0.041^{\mathrm{b}}$ & $0.019^{\mathrm{c}}$ & $0.027^{\mathrm{bc}}$ & $0.037^{\mathrm{bc}}$ & 0.007 \\
P, \% of CP & $100^{\mathrm{a}}$ & $88.6^{\mathrm{ab}}$ & $81.3^{\mathrm{b}}$ & $87.5^{\mathrm{a}}$ & $94.6^{\mathrm{ab}}$ & $97.6^{\mathrm{a}}$ & $97.9^{\mathrm{a}}$ & 5.13 \\
RUP, \% of CP & $46.4^{\mathrm{f}}$ & $71.7^{\mathrm{a}}$ & $63.7^{\mathrm{bc}}$ & $59.1^{\mathrm{cd}}$ & $67.5^{\mathrm{b}}$ & $60.3^{\mathrm{cd}}$ & $53.6^{\mathrm{e}}$ & 1.6 \\
IDP, \% of RUP & $86.7^{\mathrm{a}}$ & $59.2^{\mathrm{d}}$ & $76.8^{\mathrm{b}}$ & $74.2^{\mathrm{b}}$ & $63.0^{\mathrm{cd}}$ & $68.1^{\mathrm{c}}$ & $65.8^{\mathrm{c}}$ & 2.4 \\
IADP, \% of CP & $40.3^{\mathrm{bc}}$ & $42.4^{\mathrm{b}}$ & $59.0^{\mathrm{a}}$ & $44.0^{\mathrm{b}}$ & $42.4^{\mathrm{b}}$ & $41.1^{\mathrm{b}}$ & $35.5^{\mathrm{c}}$ & 2.7 \\
TDP, \% of CP & $93.9^{\mathrm{a}}$ & $70.7^{\mathrm{d}}$ & $85.3^{\mathrm{b}}$ & $84.9^{\mathrm{b}}$ & $74.9^{\mathrm{d}}$ & $80.8^{\mathrm{c}}$ & $81.9^{\mathrm{bc}}$ & 1.4 \\
\hline
\end{tabular}

${ }^{\mathrm{a}-\mathrm{f}}$ Means in rows with different superscripts differ $(P<0.05)$.

${ }^{1}$ Least squares means.

${ }^{2}$ Soluble fraction.

${ }^{3}$ Ruminally degradable fraction.

${ }^{4}$ Potential extent of degradation.

${ }^{5} \mathrm{RUP}=100-(\mathrm{A}+\mathrm{B} \times\{$ rate/[rate + passage rate $\left.(0.068 / \mathrm{h})]\}\right)(\emptyset$ rskov and McDonald, 1979).

${ }^{6} \mathrm{IDP}=$ estimated intestinal protein digestibility (Calsamiglia and Stern, 1995).

${ }^{7} \mathrm{IADP}=$ intestinally absorbable dietary protein; IADP $=$ RUP $\times$ IDP.

${ }^{8} \mathrm{TDP}=$ total digestible dietary protein; $\mathrm{TDP}=100(\mathrm{RUP})+\mathrm{IADP}$. 
rate in the DG sources ranging from 0.019 to $0.041 / \mathrm{h}$. The NRC (2001) assumed that the unavailable fraction of CP in the rumen to be $0.9 \%$ of $\mathrm{CP}$ and was found to be completely degradable in this experiment. This fraction in DG evaluated in this experiment had a range of 2.1 to $18.7 \%$ of $\mathrm{CP}$ which is similar to that found in the NRC $(2001 ; 8.2 \%)$.

The RUP was highest in DG1, intermediate in DG2 and DG4, and lowest in DG3 and DG5. Brouk (1994) found the RUP to range from 53.5 to $87.2 \%$ of $\mathrm{CP}$ among various sources of DG, and Harty et al. (1998) found the range of RUP in DDG to be from 47.8 to $62.6 \%$. The RUP values in this study were within these ranges (53.6 to $71.4 \%$ of the CP). The NRC (2001) estimated the RUP of DDG in a cow fed $50 \%$ forage to be $50 \%$ of CP, which is less than what was found in this study. This may partially be the result of the protein sources not being ground before the experiment. As previously discussed, particle size is one of the characteristics that will have a major effect on the degradability of a feed. Grinding these protein sources before the experiment may actually underestimate RUP, because much more of the feed is being exposed than would normally occur if it were being fed to a cow. The estimated IDP was greatest for SBM (Table 5). Among the DG, DG2 and DG3 had the greatest concentration of IDP, with DG1 having the least, ranging from 59.2 to $76.8 \%$. This is comparable to previous research by Hardy et al. (1998) in which those values ranged from 73.8 to $81.9 \%$. Due to the greater extent of ruminal degradability, SBM and WDG contained 40.3 and $35.5 \%$ intestinally absorbable dietary protein (IADP; RUP as a percentage of $\mathrm{DM} \times$ percentage of IDP/100), which was less compared with DDG (range of 42.4 to $59.0 \%$ of CP). The IADP of DDG in this study was similar to that observed in past research (39.1 to 48.7\%; Harty et al., 1998). The DG2 source had the greatest proportion of IADP compared with the other sources of DDG. Theoretically, heating may have been enough to increase the RUP but not to damage the protein, thereby increasing the protein available for absorption in the small intestine. However, heating method cannot be the only factor considered, because other characteristics, such as grain differences or other processing procedures, most likely contributed to the nutrient content as well.

Of the feeds tested, SBM had the most total digestible protein (TDP; RDP as a percentage of DM + IADP). The TDP of DG1 and DG4 were lowest among the DG sources, and the TDP of WDG was similar to the remaining DDG. In this study, the concentration of ADICP and the color score, as previously discussed, were poor predictors of RDP, IDP, and TDP in the DG, with the exception of DG1. Nakamura et al. (1994) found the digestibility of various DDG to be similar in CP digestibility even though ADICP was highly variable among the DDG (7.8 to $27.9 \%$ of CP). There was also a weak relationship between ADICP and CP digestibility $\left(R^{2}=-0.24\right)$. Similarly, Harty et al. (1998) found ADICP to vary from 4.9 to $11.6 \%$ of the CP. The linear correlations of ADICP with RDP $(r=0.04)$ and IDP $(r=-0.28)$ were weak, but, as previously stated, it may have been appropriate to investigate a nonlinear relationship as well. Van Soest (1989) stated that feeds generally contain 3 to $15 \%$ of the $\mathrm{CP}$ as ADICP, and values within this range may not be high enough to pose negative effects.

Both the CNCPS (Sniffen et al., 1992) and the in situ method are the most common and acceptable methods for predicting CP degradability in the rumen. Use of a postruminal digestion procedure, as was performed in this experiment, further allows one to better evaluate the $\mathrm{CP}$ digestibility in the animal and allows for better comparison with the CNCPS. When comparing in situ with in vitro procedures (Table 5) and the CNCPS (Table 6), one is likely to expect differences, as was observed in this experiment. The differences between the 2 methods were relatively minor in SBM. The RUP in the CNCPS was 43.3 vs. $46.3 \%$ for the in situ. The CNCPS estimated that TDP was 97.0 vs. 93.9\% for in situ. Among the DDG sources, the CNCPS predicted a range of 63.3 to $70.2 \% \mathrm{RUP}$, and the in situ found the range to be 59.1 to $71.7 \%$. The CNCPS predicted TDP to range from 72.7 to $86.8 \%$, and the in situ found this range to be 70.7 to $85.3 \%$. The CNCPS and in situ did not correspond with their predictions of the RUP and TDP of WDG, which were both lower using the in situ method vs. the CNCPS. One of the failures of the CNCPS is that the CP fractions are separated using dried ground samples in specific solutions, whereas the in situ method actually takes the physical properties of the sample into account as well. Overall, it appeared that the CNCPS and the in situ method coincided well with the dry samples but appeared to be poor with the WDG.

\section{$A A$}

The AA composition of milk protein has been shown to be constant (Jacobson et al., 1970) and can be used to predict whether a feed can provide adequate AA for milk protein synthesis. Tryptophan was not measured in the feeds used in this study. The AA composition ( $\mathrm{g} / \mathrm{kg}$ of $\mathrm{CP})$ of the SBM and DG (Table 7) used in this study was within expected ranges observed in the literature (Brouk, 1994; Maiga et al., 1996; NRC, 2001). The SBM had greater concentrations of Arg and Lys and lower concentrations of Leu and Met compared 
Table 6. Crude protein degradation parameters of soybean meal (SBM), 5 sources of dried distillers grains plus solubles (DG1, DG2, DG3, DG4, and DG5), and wet distillers grains plus solubles (WDG) estimated by the Cornell Net Protein and Carbohydrate System ${ }^{1}$

\begin{tabular}{lllllllll}
\hline & \multicolumn{7}{c}{ Feed } & \\
\cline { 2 - 7 } Item & SBM & DG1 & DG2 & DG3 & DG4 & DG5 & WDG & CV $^{2}$ \\
\hline RUP, \% of CP & 43.4 & 70.2 & 67.6 & 70.7 & 69.3 & 63.3 & 61.3 & 4.39 \\
IDP, ${ }^{3} \%$ of RUP & 93.4 & 61.1 & 75.8 & 74.5 & 72.7 & 79.2 & 84.4 & 9.48 \\
IADP, 4 of CP & 40.5 & 42.9 & 51.2 & 52.7 & 50.4 & 50.1 & 51.7 & 7.69 \\
TDP, ${ }^{5} \%$ of CP & 97.0 & 72.7 & 83.6 & 82.0 & 81.1 & 86.8 & 90.4 & 6.46 \\
\hline
\end{tabular}

${ }^{1}$ Sniffen et al., 1992.

${ }^{2} \mathrm{CV}$ among DG1, DG2, DG3, DG4, and DG5.

${ }^{3} \mathrm{IDP}=$ estimated intestinal protein digestibility.

${ }^{4} \mathrm{IADP}=$ intestinally absorbable dietary protein; IADP $=\mathrm{RUP} \times \mathrm{IDP}$.

${ }^{5} \mathrm{TDP}=$ total digestible dietary protein; $\mathrm{TDP}=(100-\mathrm{RUP})+$ IADP.

with the DG. The concentration of Lys was the most variable AA among the DG sources, which ranged from 19.1 to $31.9 \mathrm{~g} / \mathrm{kg}$ of CP (CV = 13.2). Spiehs et al. (2002) found Lys to have a range of 24.6 to $33.1 \mathrm{~g} / \mathrm{kg}$ of CP in samples from 10 different ethanol plants. The greatest effect on the Lys concentration is the degree of heating, because this AA is the first one susceptible to heat damage via a Maillard reaction with the $\varepsilon$-amino group (Schwab, 1995). This may help explain why the WDG had a greater concentration of Lys compared with DG. The milk protein score (MPS; Schingoethe, 1996), which is a measure of protein quality based on the firstlimiting essential AA (EAA) of the feed, was greater in SBM (Met first limiting) compared with DG (Lys first limiting), and the MPS of WDG was greater than that of the DDG. Due to the variability in Lys levels in DDG, the MPS had a range of 0.236 to 0.333 . Use of MPS does not take differences in AA uptake into

Table 7. The AA composition of soybean meal (SBM), 5 sources of dried distillers grains plus solubles (DG1, DG2, DG3, DG4, and DG5), and wet distillers grains plus solubles (WDG) before ruminal incubation

\begin{tabular}{|c|c|c|c|c|c|c|c|c|}
\hline \multirow[b]{2}{*}{$\mathrm{AA}$} & \multicolumn{7}{|c|}{ Feed $^{1}$} & \multirow[b]{2}{*}{$\mathrm{CV}^{2}$} \\
\hline & SBM & DG1 & DG2 & DG3 & DG4 & DG5 & WDG & \\
\hline & & & & $\mathrm{g} / \mathrm{kg}$ of $\mathrm{CP})$ & & & & \\
\hline Arg & $60.5(9)^{3}$ & $33.7(8)$ & $37.1(8)$ & $39.1(9)$ & $39.9(9)$ & $39.4(9)$ & $40.4(9)$ & 6.73 \\
\hline His & $23.1(7)$ & $22.0(6)$ & $22.4(6)$ & $21.3(6)$ & $19.4(5)$ & $21.5(6)$ & $22.5(6)$ & 5.42 \\
\hline Ile & 33.1 (3) & $32.4(2)$ & $28.2(2)$ & $27.6(2)$ & $26.3(2)$ & $30.9(2)$ & $32.8(2)$ & 8.60 \\
\hline Leu & $67.8(5)$ & $116(9)$ & $113(9)$ & $107(8)$ & $110(8)$ & $105(8)$ & 111 & 4.03 \\
\hline Lys & $56.1(4)$ & $19.1(1)$ & $23.0(1)$ & $21.6(1)$ & $20.8(1)$ & $26.9(1)$ & 31.9 (1) & 13.2 \\
\hline Met & $12.4(1)$ & $19.8(5)$ & $18.4(4)$ & $16.9(4)$ & $17.7(4)$ & $17.9(5)$ & $17.2(3)$ & 6.42 \\
\hline Phe & $43.2(8)$ & $45.0(7)$ & $45.0(7)$ & $43.1(7)$ & $45.0(7)$ & $42.6(7)$ & $47.0(7)$ & 2.70 \\
\hline Thr & $33.5(6)$ & $34.2(4)$ & $32.8(5)$ & $31.4(5)$ & $37.4(6)$ & 31.1 (4) & $33.7(5)$ & 7.68 \\
\hline Val & $35.7(2)$ & $45.7(3)$ & $40.2(3)$ & $38.7(3)$ & $36.5(3)$ & $43.2(3)$ & $45.1(4)$ & 8.91 \\
\hline Total EAA ${ }^{4}$ & 371.3 & 368.6 & 360.1 & 346.6 & 352.7 & 358.4 & 382.2 & 2.31 \\
\hline MPS $^{5}$ & 0.476 & 0.236 & 0.284 & 0.267 & 0.257 & 0.333 & 0.394 & 13.3 \\
\hline Ala & 40.5 & 71.8 & 55.0 & 67.2 & 74.5 & 68.7 & 73.5 & 11.1 \\
\hline Asp + Asn & 120.8 & 67.4 & 51.2 & 69.9 & 73.3 & 65.8 & 71.4 & 13.0 \\
\hline Cys + cystine & 16.4 & 20.0 & 19.7 & 20.5 & 20.4 & 19.5 & 20.4 & 2.16 \\
\hline $\mathrm{Glu}$ + Gln & 173.0 & 172.5 & 174.2 & 170.9 & 168.6 & 161.9 & 166.6 & 2.82 \\
\hline Gly & 38.9 & 36.1 & 36.8 & 35.8 & 36.8 & 35.8 & 37.1 & 1.40 \\
\hline Pro & 47.8 & 76.6 & 78.7 & 75.2 & 78.3 & 71.3 & 74.4 & 3.93 \\
\hline Ser & 55.3 & 49.8 & 59.1 & 52.3 & 52.2 & 49.4 & 52.1 & 7.40 \\
\hline Total NEAA 6 & 492.7 & 494.3 & 474.7 & 491.7 & 504.1 & 472.4 & 495.4 & 2.77 \\
\hline
\end{tabular}

${ }^{1}$ One observation per feed, so statistical analysis was not performed.

${ }^{2} \mathrm{CV}$ among DG1, DG2, DG3, DG4, and DG5.

${ }^{3}$ Numbers in parentheses indicate the apparent sequence of limiting AA based on estimates of the AA profile of milk protein (Jacobson et al., 1970).

${ }^{4} \mathrm{EAA}=$ essential AA; Trp was not determined.

${ }^{5} \mathrm{MPS}=$ milk protein score; MPS = (g of first-limiting AA in feed $/ \mathrm{kg}$ of feed protein $) /(\mathrm{g}$ of first limiting AA in milk/kg of milk protein) (Schingoethe, 1996).

${ }^{6} \mathrm{NEAA}=$ nonessential AA. 
Table 8. The AA composition of soybean meal (SBM), 5 sources of dried distillers grains plus solubles (DG1, DG2, DG3, DG4, and DG5), and wet distillers grains plus solubles (WDG) remaining after $12 \mathrm{~h}$ of ruminal incubation $^{1}$

\begin{tabular}{|c|c|c|c|c|c|c|c|c|}
\hline \multirow[b]{2}{*}{$\mathrm{AA}$} & \multicolumn{7}{|c|}{ Feed $^{2}$} & \multirow[b]{2}{*}{$\mathrm{SE}$} \\
\hline & SBM & DG1 & DG2 & DG3 & DG4 & DG5 & WDG & \\
\hline $\mathrm{CP}, \%$ of $\mathrm{DM}$ & $77.5^{\mathrm{a}}$ & $41.5^{\mathrm{a}}$ & $40.1^{b}$ & $40.5^{\mathrm{ab}}$ & $40.9^{\mathrm{ab}}$ & $38.7^{\mathrm{c}}$ & $37.1^{\mathrm{d}}$ & 0.048 \\
\hline Arg & $62.9^{\mathrm{a}}(9)^{3}$ & $29.9^{\mathrm{c}}(7)$ & $35.8^{\mathrm{b}}(8)$ & $34.9^{\mathrm{b}}(8)$ & $35.2^{\mathrm{b}}(7)$ & $32.4^{\mathrm{bc}}(7)$ & $34.4^{\mathrm{b}}(7)$ & 1.6 \\
\hline His & $21.6^{\mathrm{a}}(6)$ & $18.7^{\mathrm{bc}}(4)$ & $20.0^{\mathrm{abc}}(5)$ & $18.7^{\mathrm{bc}}(5)$ & $19.5^{\mathrm{abc}}(6)$ & $17.5^{\mathrm{c}}(4)$ & $17.4^{\mathrm{c}}(4)$ & 0.8 \\
\hline Ile & $36.2^{\mathrm{a}}(3)$ & $24.1^{\mathrm{b}}(2)$ & $30.1^{\mathrm{ab}}(2)$ & $29.2^{\mathrm{ab}}(2)$ & $28.4^{\mathrm{b}}(2)$ & $25.6^{\mathrm{b}}(2)$ & $28.0^{\mathrm{b}}(2)$ & 2.6 \\
\hline Leu & $72.0^{\mathrm{b}}(5)$ & $116^{\mathrm{a}}(9)$ & $123^{\mathrm{a}}(9)$ & $122^{\mathrm{a}}(9)$ & $119^{\mathrm{a}}(9)$ & $112^{\mathrm{a}}(9)$ & $121^{\mathrm{a}}(9)$ & 4.4 \\
\hline Lys & $55.2^{\mathrm{a}}(4)$ & $16.6^{\mathrm{e}}(1)$ & $21.0^{\text {cd }}(1)$ & $18.8^{\mathrm{de}}(1)$ & $19.1^{\text {cde }}(1)$ & $21.8^{\mathrm{c}}(1)$ & $24.8^{\mathrm{b}}(1)$ & 1.0 \\
\hline Met & $12.8^{\mathrm{b}}(1)$ & $19.4^{\mathrm{a}}(5)$ & $18.0^{\mathrm{a}}(4)$ & $18.0^{\mathrm{a}}(4)$ & $17.8^{\mathrm{a}}(4)$ & $17.4^{\mathrm{a}}(5)$ & $17.5^{\mathrm{a}}(5)$ & 1.0 \\
\hline Phe & $47.4^{\mathrm{ab}}(8)$ & $47.0^{\mathrm{ab}}(8)$ & $48.8^{\mathrm{ab}}(7)$ & $46.8^{\mathrm{ab}}(7)$ & $49.8^{\mathrm{ab}}(8)$ & $45.6^{\mathrm{b}}(8)$ & $51.6^{\mathrm{a}}(8)$ & 1.7 \\
\hline Thr & $38.9^{\mathrm{a}}(7)$ & $34.5^{\mathrm{b}}(6)$ & $34.6^{\mathrm{b}}(6)$ & $33.3^{\mathrm{b}}(6)$ & $33.1^{\mathrm{b}}(5)$ & $32.2^{\mathrm{b}}(6)$ & $33.4^{b}(6)$ & 1.5 \\
\hline Val & $39.9(2)$ & $39.6(3)$ & $41.6(3)$ & $38.3(3)$ & $38.7(3)$ & $34.8(3)$ & $37.0(3)$ & 2.7 \\
\hline Total $\mathrm{EAA}^{4}$ & $386.9^{\mathrm{a}}$ & $346.4^{\mathrm{ab}}$ & $372.5^{\mathrm{ab}}$ & $360.5^{\mathrm{ab}}$ & $360.2^{\mathrm{ab}}$ & $338.9^{\mathrm{b}}$ & $360.1^{\text {ab }}$ & 14.8 \\
\hline MPS $^{5}$ & $0.491^{\mathrm{a}}$ & $0.205^{\mathrm{e}}$ & $0.260^{\mathrm{cd}}$ & $0.232^{\mathrm{de}}$ & $0.236^{\text {cde }}$ & $0.269^{c}$ & $0.306^{\mathrm{b}}$ & 0.012 \\
\hline Ala & $48.1^{\mathrm{c}}$ & $76.1^{\mathrm{b}}$ & $77.5^{\mathrm{ab}}$ & $74.5^{\mathrm{b}}$ & $79.3^{\mathrm{ab}}$ & $74.9^{\mathrm{b}}$ & $82.7^{\mathrm{a}}$ & 2.3 \\
\hline$A s p+A s n$ & $134.1^{\mathrm{a}}$ & $69.9^{\mathrm{b}}$ & $72.8^{\mathrm{b}}$ & $72.5^{\mathrm{b}}$ & $70.2^{\mathrm{b}}$ & $70.4^{\mathrm{b}}$ & $75.5^{\mathrm{b}}$ & 2.8 \\
\hline Cys + cystine & 17.9 & 20.4 & 19.5 & 19.1 & 19.0 & 18.1 & 17.9 & 1.1 \\
\hline $\mathrm{Glu}+\mathrm{Gln}$ & $163.5^{\mathrm{c}}$ & $176.2^{\mathrm{abc}}$ & $177.2^{\mathrm{abc}}$ & $173.7^{\mathrm{abc}}$ & $179.0^{\mathrm{ab}}$ & $164.9^{\mathrm{bc}}$ & $183.0^{\mathrm{a}}$ & 5.6 \\
\hline Gly & $41.7^{\mathrm{a}}$ & $32.0^{\mathrm{b}}$ & $32.4^{\mathrm{b}}$ & $32.0^{\mathrm{b}}$ & $31.0^{\mathrm{b}}$ & $30.6^{\mathrm{b}}$ & $31.9^{\mathrm{b}}$ & 1.0 \\
\hline Pro & $47.3^{\mathrm{b}}$ & $65.6^{\mathrm{a}}$ & $77.0^{\mathrm{a}}$ & $74.2^{\mathrm{a}}$ & $78.0^{\mathrm{a}}$ & $69.1^{\mathrm{a}}$ & $75.0^{\mathrm{a}}$ & 5.0 \\
\hline Ser & $57.1^{\mathrm{a}}$ & $49.8^{\mathrm{b}}$ & $50.5^{\mathrm{b}}$ & $50.3^{\mathrm{b}}$ & $51.4^{\mathrm{b}}$ & $49.8^{\mathrm{b}}$ & $53.5^{\mathrm{ab}}$ & 1.8 \\
\hline Total NEAA ${ }^{6}$ & 509.6 & 490.0 & 506.8 & 496.3 & 507.9 & 477.9 & 519.3 & 15.9 \\
\hline
\end{tabular}

${ }^{\mathrm{a}-\mathrm{e}}$ Means in rows with different superscripts differ $(P<0.05)$.

${ }^{1}$ Least squares means.

${ }^{2}$ Six observations per feed.

${ }^{3}$ Numbers in parentheses indicate the apparent sequence of limiting AA based on estimates of the AA profile of milk proteins (Jacobson et al., 1970).

${ }^{4} \mathrm{EAA}=$ essential AA; Trp was not determined.

${ }^{5} \mathrm{MPS}=$ milk protein score MPS = (g of first-limiting AA in residue/kg of residue protein $) /(\mathrm{g}$ of first limiting AA in milk/kg of milk protein) (Schingoethe, 1996).

${ }^{6} \mathrm{NEAA}=$ nonessential AA.

account, such as measuring mammary gland arterialvenous differences. However, it is a viable estimate of how adequately the dietary AA may potentially support milk protein synthesis.

The AA profile of the protein sources in this study remaining after $12 \mathrm{~h}$ of ruminal incubation (Table 8) did not change considerably compared with prior to ruminal incubation. The AA concentration of the 12$\mathrm{h}$ residues is approximately reflective of the RUP fraction in the protein sources. As in the original feed samples, according to MPS, Met was first limiting in SBM, and Lys was first limiting in DG. In SBM, Val and Ile were the second- and third-limiting AA, respectively, and Ile and Val were second and third limiting in DG, respectively. Overall, the concentration of total EAA was similar among feeds, except SBM had more EAA compared with DG5. Among the feeds in this study, SBM had the highest MPS, followed by WDG. Among the DDG, DG1 numerically had the lowest MPS but was significantly lower than DG2 and DG5.

The estimated dietary metabolizable EAA $(\mathrm{g} / \mathrm{kg}$ of CP consumed) is shown in Table 9 . As previously men- tioned, Met was the first-limiting AA in SBM and Lys in DG. For all protein sources, Val and Ile were the next 2 limiting EAA. With the exception of DG5, DG2 provided the most dietary Lys postruminally compared with the other sources of DDG. The DG2 source also provided the greatest amount of dietary EAA to the small intestine compared with the other protein sources with the exception of DG3. In a companion lactation study, Kleinschmit et al. (2006) compared SBM, DG1, DG2, or DG3 as the primary protein sources in a protein-deficient diet. In that study, Lys was the first-limiting EAA for milk protein synthesis in DG1 and DG3 but not in DG2, which corresponds to the greater supply of intestinal Lys observed in this experiment. Furthermore, the protein content in the milk and concentrations of Lys in plasma tended $(P<$ 0.10 ) to be greater for cows fed DG2 and DG3 compared with DG1 in the companion study by Kleinschmit et al. (2006). Even though DG3 provided similar amounts of postruminal Lys as DG1, it was more degradable in the rumen and most likely stimulated greater synthesis of microbial protein, which is an excellent source 
Table 9. Estimated dietary metabolizable essential AA (corrected for indigestible RUP) from soybean meal (SBM), 5 sources of dried distillers grains plus solubles (DG1, DG2, DG3, DG4, and DG5), and wet distillers grains plus solubles (WDG) ${ }^{1}$

\begin{tabular}{|c|c|c|c|c|c|c|c|c|}
\hline \multirow[b]{2}{*}{$\mathrm{AA}$} & \multicolumn{7}{|c|}{ Feed $^{2}$} & \multirow[b]{2}{*}{ SE } \\
\hline & SBM & DG1 & DG2 & DG3 & DG4 & DG5 & WDG & \\
\hline & \multicolumn{7}{|c|}{$-\left(\mathrm{g} / \mathrm{kg}\right.$ of $\mathrm{CP}$ consumed $\left.^{3}\right)$} & \\
\hline Arg & $25.4^{\mathrm{a}}(9)^{4}$ & $12.7^{\mathrm{cd}}(7)$ & $17.6^{\mathrm{b}}(8)$ & $15.3^{\mathrm{bc}}(8)$ & $14.9^{\text {bcd }}(7)$ & $13.4^{\mathrm{cd}}(7)$ & $12.1^{\mathrm{d}}(7)$ & 1.41 \\
\hline His & $8.7^{\mathrm{ab}}(6)$ & $7.9^{\mathrm{bc}}(4)$ & $9.8^{\mathrm{a}}(5)$ & $8.2^{\mathrm{bc}}(5)$ & $8.2^{\mathrm{bc}}(6)$ & $7.2^{\text {cd }}(4)$ & $6.1^{\mathrm{d}}(4)$ & 0.51 \\
\hline Ile & $14.7^{\mathrm{a}}(3)$ & $10.2^{\mathrm{b}}(2)$ & $14.8^{\mathrm{a}}(2)$ & $12.8^{\mathrm{ab}}(2)$ & $12.0^{\mathrm{ab}}(2)$ & $10.6^{\mathrm{b}}(2)$ & $9.8^{\mathrm{b}}(2)$ & 1.33 \\
\hline Leu & $29.2^{\mathrm{d}}(5)$ & $49.4^{\mathrm{bc}}(9)$ & $60.1^{\mathrm{a}}(9)$ & $53.6^{\mathrm{ab}}(9)$ & $50.4^{\text {bc }}(9)$ & $45.7^{\mathrm{c}}(9)$ & $42.7^{\mathrm{c}}(9)$ & 2.95 \\
\hline Lys & $22.3^{\mathrm{a}}(4)$ & $7.0^{\mathrm{c}}(1)$ & $10.4^{\mathrm{b}}(1)$ & $8.3^{\mathrm{c}}(1)$ & $8.1^{\mathrm{c}}(1)$ & $9.0^{\mathrm{bc}}$ & $8.8^{\mathrm{bc}}(1)$ & 0.91 \\
\hline Met & $5.2^{\mathrm{d}}(1)$ & $8.2^{\mathrm{ab}}(5)$ & $8.8^{\mathrm{a}}(4)$ & $8.0^{\mathrm{ab}}(4)$ & $7.5^{\mathrm{b}}(4)$ & $7.2^{\text {bc }}(5)$ & $6.2^{\text {cd }}(5)$ & 0.58 \\
\hline Phe & $19.1^{\mathrm{b}}(8)$ & $19.8^{\mathrm{b}}(8)$ & $24.0^{\mathrm{a}}(7)$ & $20.6^{\mathrm{b}}(7)$ & $21.1^{\mathrm{ab}}(8)$ & $18.8^{\mathrm{b}}(8)$ & $18.1^{\mathrm{b}}(8)$ & 1.29 \\
\hline Thr & $15.7^{\mathrm{ab}}(7)$ & $14.6^{\text {bc }}(6)$ & $17.0^{\mathrm{a}}(6)$ & $14.7^{\mathrm{bc}}(6)$ & $13.9^{\text {bcd }}(5)$ & $13.3^{\text {cd }}(6)$ & $11.9^{\mathrm{d}}(6)$ & 0.94 \\
\hline Val & $16.2^{\mathrm{bc}}(2)$ & $16.6^{\mathrm{b}}(3)$ & $20.5^{\mathrm{a}}(3)$ & $16.9^{b}(3)$ & $16.3^{\mathrm{bc}}(3)$ & $14.3^{\mathrm{bc}}(3)$ & $13.0^{\mathrm{c}}(3)$ & 1.32 \\
\hline Total EAA ${ }^{5}$ & $156.4^{\mathrm{b}}$ & $146.3^{\mathrm{bc}}$ & $182.9^{\mathrm{a}}$ & $158.3^{\mathrm{ab}}$ & $152.4^{\mathrm{bc}}$ & $139.4^{\mathrm{bc}}$ & $128.7^{\mathrm{c}}$ & 10.23 \\
\hline MPS $^{6}$ & $0.427^{\mathrm{a}}$ & $0.121^{\mathrm{d}}$ & $0.200^{\mathrm{b}}$ & $0.173^{b c}$ & $0.148^{\mathrm{cd}}$ & $0.184^{\mathrm{b}}$ & $0.201^{\mathrm{b}}$ & 0.011 \\
\hline
\end{tabular}

${ }^{\mathrm{a}-\mathrm{d}}$ Means in rows with different superscripts differ $(P<0.05)$.

${ }^{1}$ Least squares means.

${ }^{2}$ Six observations per feed.

${ }^{3}$ (AA residue after $12 \mathrm{~h}$ of ruminal exposure, $\mathrm{g} / \mathrm{kg}$ )(RUP percentage/100)(percentage of intestinally absorbable dietary protein/100).

${ }^{4}$ Numbers in parentheses indicate the apparent sequence of limiting AA based on estimates of the AA profile of milk proteins (Jacobson et al., 1970).

${ }^{5} \mathrm{EAA}=$ essential AA; Trp was not determined.

${ }^{6} \mathrm{MPS}=$ milk protein score $=[(\mathrm{g}$ of first-limiting $\mathrm{AA}$ in digestible residue $/ \mathrm{kg}$ of residue protein $)(\%$ of intestinally absorbable dietary protein/100)]/(g of first limiting AA in milk/kg of milk protein) (Schingoethe, 1996).

of Lys (Clark et al., 1992). Similarly, Anderson et al. (2006) compared DG5 and WDG, which were obtained from the same ethanol plant, and found that cows fed WDG produced milk with a greater protein concentration compared with DG5 (3.02 vs. 3.09\% for DG5 and WDG, respectively). Both sources provided similar amounts of metabolizable Lys in this experiment, but the WDG was more degradable in the rumen, which may have allowed greater synthesis of microbial protein. Within each of the lactation experiments, yields of milk or ECM were not affected by DG sources, which indicates that variation of DG source is probably more prone to affect protein availability compared with the availability of other constituents. This was indicated in the fact that the extent of NDF digestion was not affected by DG source in this study.

\section{CONCLUSIONS}

In this study, CP in SBM was highly degradable in the rumen, which may potentially support more microbial protein synthesis than the DG sources evaluated. The CP in WDG was more ruminally available compared with DDG, but estimated total tract digestibility was similar among WDG and some of the DDG sources. Adequate drying may shift the site of protein digestion without damaging the protein, as demonstrated in DG5 and WDG; they were processed using similar methods, except for the drying of DG5. Methionine was the first limiting EAA in SBM, and Lys was the first limiting EAA in DG. The dietary metabolizable EAA was fairly similar among sources of DDG with the exception of one source that provided more EAA and Lys compared with the others. In conclusion, protein degradability and digestibility differed greatly among DG sources, but these differences were actually not as prominent in the concentrations of metabolizable AA and MPS among these sources.

\section{ACKNOWLEDGMENTS}

We thank Darrel Rennich and the personnel at the South Dakota State University Dairy Teaching and Research Farm for the feeding, milking, and care of the animals. This project was partially funded by the Dakota Gold Research Association, Scotland, South Dakota.

\section{REFERENCES}

Anderson, J. L., D. J. Schingoethe, K. F. Kalscheur, and A. R. Hippen. 2006. Evaluation of dried and wet distillers grains included at two concentrations in the diets of lactating dairy cows. J. Dairy Sci. 89:3133-3142.

AOAC. 2000. Official Methods of Analysis. 17th ed. AOAC Int., Gaithersburg, MD.

ASAE. 2004. ASAE Standards 2004. Am. Soc. Agric. Eng., St. Joseph, MI. 
Brouk, M. J. 1994. Net energy for lactation and ruminal degradability of wet corn distillers grains. PhD Diss. South Dakota State Univ., Brookings.

Calsamiglia, S., and M. D. Stern. 1995. A three-step in vitro procedure for estimating intestinal digestion of protein in ruminants. J. Anim. Sci. 73:1459-1465.

Clark, J. H., T. H. Klusmeyer, and M. R. Cameron. 1992. Microbial protein synthesis and flows of nitrogen fractions to the duodenum of dairy cows. J. Dairy Sci. 75:2304-2323.

Clark, J. H., M. R. Murphy, and B. A. Crooker. 1987. Supplying the protein needs of dairy cattle from by-product feeds. J. Dairy Sci. 70:1092-1109.

Cromwell, G. L., K. L. Herkelman, and T. S. Stahly. 1993. Physical, chemical, and nutritional characteristics of distillers dried grains with solubles for chicks and pigs. J. Anim. Sci. 71:679-686.

Cyriac, J., M. M. Abdelqader, K. F. Kalscheur, A. R. Hippen, and D. J. Schingoethe. 2005. Effect of replacing forage fiber with nonforage fiber in lactating dairy cow diets. J. Dairy Sci. 88(Suppl. 1):252. (Abstr.)

Firkins, J. L., L. L. Berger, G. C. Fahey Jr., and N. R. Merchen. 1984. Ruminal nitrogen degradability and escape of wet and dry distillers grains and wet and dry corn gluten feeds. J. Dairy Sci. 67:1936-1944.

Goering, H. K., C. H. Gordon, R. W. Hemken, D. R. Waldo, P. J. Van Soest, and L. W. Smith. 1972. Analytical estimates of nitrogen digestibility in heat damaged forages. J. Dairy Sci. 55:1275-1280.

Harty, S. R., J.-M. Akayezu, J. G. Linn, and J. M. Cassady. 1998. Nutrient composition of distillers grains with added solubles. J. Dairy Sci. 81(Suppl. 1):1201. (Abstr.)

Hunter Associates Laboratory. 2002. Universal Software User's Manual, Version 2.5. Hunter Assoc., Reston, VA.

Jacobson, D. R., H. H. Van Horn, and C. J. Sniffen. 1970. Lactating ruminants. Fed. Proc. 29:35-40.

Kleinschmit, D. H., D. S. Schingoethe, K. F. Kalscheur, and A. R. Hippen. 2006. Evaluation of various sources of corn distillers dried grains plus solubles for lactating dairy cattle. J. Dairy Sci. 89:4784-4794.

Licitra, G., T. M. Hernandez, and P. J. Van Soest. 1996. Standardization of procedures for nitrogen fractionation of ruminant feeds. Anim. Feed Sci. Technol. 57:347-358.

Littell, G. C., G. A. Milliken, S. W. Walter, and R. D. Wolfinger. 1996. SAS Systems for Mixed Models. SAS Inst. Inc., Cary, NC.

Liu, C., D. J. Schingoethe, and G. A. Stegeman. 2000. Corn distillers grains versus a blend of protein supplements with or without ruminally protected amino acids for lactating cows. J. Dairy Sci. 83:2075-2084.

Maiga, H. A., D. J. Schingoethe, and J. E. Henson. 1996. Ruminal degradation, amino acid composition, and intestinal digestibility of the residual components of five protein supplements. J. Dairy Sci. 79:1647-1653.

McDonald, I. 1981. A revised model for the estimation of protein degradability in the rumen. J. Agric. Sci. (Camb.) 96:251-252.

Nakamura, T., T. J. Klopfenstein, and R. A. Britton. 1994. Evaluation of acid detergent insoluble nitrogen as an indicator of protein quality in nonforage proteins. J. Anim. Sci. 72:1043-1048.
Nichols, J. R., D. J. Schingoethe, H. A. Maiga, M. J. Brouk, and M. S. Piepenbrink. 1998. Evaluation of corn distillers grains and ruminally protected lysine and methionine for lactating dairy cows. J. Dairy Sci. 81:482-491.

NRC. 2001. Nutrient Requirements of Dairy Cattle. 7th rev. ed. Natl. Acad. Sci., Washington, DC.

Ørskov, E. R., and I. McDonald. 1979. The estimation of protein degradability in the rumen from incubation measurements weighted according to rate of passage. J. Agric. Sci. Camb. 92:499-503.

Poos-Floyd, M., T. Klopfenstein, and R. A. Britton. 1985. Evaluation of laboratory techniques for predicting ruminal protein degradation. J. Dairy Sci. 68:829-839.

Robertson, J. B., and P. J. Van Soest. 1981. The detergent system of analysis and its application to human foods. Pages 123-158 in The Analysis of Dietary Fiber in Food. W. P. T. James and O. Theander, ed. Marcel Dekker Inc., New York, NY.

Santini, F. J., A. R. Hardie, N. A. Jorgensen, and M. F. Finner. 1983. Proposed use of adjusted intake based on forage particle length for calculation of roughage indexes. J. Dairy Sci. 66:811-820.

SAS Institute. 1999. SAS User's Guide: Statistics. Version 8.01 ed. SAS Inst. Inc., Cary, NC.

Schingoethe, D. J. 1996. Balancing the amino acid needs of the dairy cow. Anim. Feed Sci. Technol. 60:153-160.

Schwab, C. G. 1995. Protected proteins and amino acids for ruminants. Pages 115-141 in Biotechnology in Animal Feeds and Animal Feeding. R. J. Wallace and A. Chesson, ed. VCH Press, Weinheim, Germany.

Sniffen, C. J., J. D. O'Connor, P. J. Van Soest, D. G. Fox, and J. B. Russell. 1992. A net carbohydrate and protein system for evaluating cattle diets. II. Carbohydrate and protein availability. J. Anim. Sci. 70:3562-3577.

Spiehs, M. J., M. H. Whiteny, and G. C. Shurson. 2002. Nutrient database for distiller's dried grains with solubles produced from new ethanol plants in Minnesota and South Dakota. J. Anim. Sci. 80:2639-2645.

Stern, M. D., G. A. Varga, J. H. Clark, J. L. Firkins, J. T. Huber, and D. L. Palmquist. 1994. Evaluation of chemical and physical properties of feeds that affect protein metabolism in the rumen. J. Dairy Sci. 77:2762-2786.

Van Soest, P. J. 1989. On the digestibility of bound $\mathrm{N}$ in distillers grains: A reanalysis. Pages 127-135 in Proc. Cornell Nutr. Conf. Feed Manuf. Cornell Univ., Ithaca, NY.

Van Soest, P. J., J. B. Robertson, and B. A. Lewis. 1991. Methods for dietary fiber, neutral detergent fiber, and nonstarch polysaccharides in relation to animal nutrition. J. Dairy Sci. 74:35833597.

Weiss, W. P., D. O. Erickson, G. M. Erickson, and G. R. Fisher. 1989. Barley distillers grains as a protein supplement for dairy cows. J. Dairy Sci. 72:980-987.

Yu, Y., and J. W. Thomas. 1976. Estimation of the extent of heat damage in alfalfa haylage by laboratory measurements. J. Anim. Sci. 42:766-774. 